\title{
Pemberdayaan Masyarakat melalui Edukasi Pengelolaan BUMDes dan Sumber Daya Desa sebagai Pilar PPKM (Penggerak Perekonomian Kawasan Masyarakat) Perdesaan pada Masa Pandemi
}

\author{
Abdulrahim Maruwae ${ }^{1}$, Boby Rantow Payu ${ }^{2}$ \\ ${ }^{1}$ Jurusan Pendidikan Ekonomi, Fakultas Ekonomi, Universitas Negeri Gorontalo, Jl. Jend. \\ Sudirman No. 6 Kota Gorontalo, Gorontalo 96128, Indonesia \\ 2 Jurusan Ekonomi Pembangunan, Fakultas Ekonomi, Universitas Negeri Gorontalo, J1. Jend. \\ Sudirman No. 6 Kota Gorontalo, Gorontalo 96128, Indonesia \\ E-mail: uli@ung.ac.id ${ }^{1}$, boby_rantow@yahoo.com ${ }^{2}$
}

Article History:

Received: 023-11-2021

Revised: 29-11-2021

Accepted: 30-11-2021

Keywords: Pengelolaan

BUMDes, Sumber Daya Desa

\begin{abstract}
:
Salah satu pilar dalam pembangunan desa dan dianggap sebagai penggerak perekonomian dimasa pandemi yang dapat dikembangkan potensinya yaitu keberadaan badan usaha milik desa (BUMDes). Pengabdian ini bertujuan mengidentifikasi potensi strategis desa dalam rangka mendukung pengembangan BUMDes dan pengelolaan sumber daya desa. Metode yang ditempuh yaitu dengan memberikan edukasi pengelolaan BUMDes dan sumber daya desa sebagai pilar PKKM perdesaan pada masa pandemi bagi pengelola BUMDes, aparat desa, pengurus $B P D$, dan elemen masyarakat lainnya. Hasil yang dicapai dalam pelaksaaan pengabdian ini yait: 1). terbentuknya kesamaan pandangan dalam mengelola BUMDes khususnya pengurus/pengelola, pemerintah desa, pengurus BPD dan masyarakat dalam mengawal pengembangan BUMDes di Desa Paris dan Desa Karyamukti Kecamatan Mootilango Kabupaten Gorontalo. 2). meningkatnya pengetahuan masyarakat dan pengelola BUMDes dalam memilih usaha yang sesuai dengan potensi desa, dan 3). Meningkatnya partisipasi aktif masyarakat dalam menjawab segala masalah yang dihadapi dalam pengelolaan BUMDes.
\end{abstract}

\section{Pendahuluan}

Pembangunan kawasan perdesaan yang terus diupayakan secara berkelanjutan melalui program-program pemerintah dan pihak lainnya menjadi lebih fokus dengan dioptimalkannya dana desa sebagai penggerak ekonomi dan ketahanan masyarakat. Salah satu pilar dalam pembangunan desa dan dianggap sebagai penggerak perekonomian dimasa pandemi yang dapat dikembangkan potensinya yaitu keberadaan Badan Usaha Milik Desa (BUMDes). Namun dalam beberapa riset, peran BUMDes sebagai penggerak perekonomian perdesaan belum bergerak secara optimal. Keberadaan BUMDes masih belum bisa berjalan efektif dan mampu memberi kontribusi bagi pembangunan dan pemberdayaan masyarakat di desa tersebut (Prasetyo, 2017:87).

Lebih lanjut Prasetyo (2017:86) mengungkapkan bahwa partisipasi masyarakat dalam kegiatan BUMDes masih kurang karena pengetahuan masyarakat terhadap program BUMDes masih sedikit. Dengan demikian, optimalisasi potensi pengembangan BUMDes dapat terus 
diupayakan dan menjadi bagian dari program pembangunan desa. Apalagi dimasa pandemi dengan aturan PPKM seperti saat ini, BUMDes diharapkan dapat mengoptimalkan kegiatan usaha terutama dalam memberdayakan sumber daya dan aset desa melalui platform digital.

Pemilihan Desa Paris dan Desa Karyamukti Kecamatan Mootilango sebagai sasaran mitra pengabdian disebabkan desa tersebut menjadi proyeksi desa binaan Fakultas Ekonomi Universitas Negeri Gorontalo dalam ragam aktivitas kegiatan usaha mikro dan kegiatan lainnya. Di samping itu juga, kedua desa ini juga sebagian besar penduduknya bekerja sebagai petani, pedagang, buruh, penjahit, tukang, PNS dan TNI. Desa Paris dan Desa Karyamukti ini terletak di dataran rendah wilayah bagian timur Kecamatan Mootilango yang memanjang dari utara ke selatan. Keadaan tipografi didominasi oleh dataran rendah dan hanya terdapat bukit kecil yang rata-rata memiliki ketinggian kurang lebih 50 Meter. Jarak tempuh ke pusat pemerintahan kecamatan Mootilango kurang lebih 2 Kilometer yang dapat ditempuh dengan menggunakan kenderaan bermotor.

Keadaan sosial masyarakat Desa Paris dan Desa Karyamukti masih tergolong pada masyarakat dibawah garis menengah kebawah dan mengingat potensi yang dimiliki seperti minat untuk bekerja dan berusaha cukup besar maka dipandang perlu untuk melakukan edukasi pengelolaan BUMDes dan sumber daya desa sebagai pilar Penggerak Perekonomian Kawasan Masyarakat (PPKM) perdesaan pada masa pandemi.

Melalui program pengabdian ini diharapkan dapat menjembatani pengembangan dan penerapan inovasi dan teknologi yang berguna secara langsung pada masyarakat untuk meningkatkan ekonomi dan penanganan sosial, budaya dan kesehatan (TOR KKN Tematik Desa Membangun). Untuk mencapai strategi tersebut kami dari staf dosen Fakultas Ekonomi Universitas Negeri Gorontalo mencoba memformulasikannya ke dalam Program Pengabdian Masyarakat dengan judul "Pemberdayaan Masyarakat melalui Edukasi Pengelolaan BUMDes dan Sumber Daya Desa sebagai Pilar PPKM (Penggerak Perekonomian Kawasan Masyarakat) Perdesaan pada Masa Pandemi”.

\section{Metode}

Desa yang menjadi mitra pengabdian merupakan daerah yang terletak di dataran rendah dan hanya terdapat bukit kecil yang rata-rata memiliki ketinggian kurang lebih 50 Meter. Sebagian besar masyarakat di Desa Paris dan Desa Karyamukti bermata pencaharian sebagai petani, pedagang, buruh, penjahit, tukang, PNS dan TNI. Mempertimbangkan kondisi sebagian besar masyarakat dengan pendapatan menengah kebawah dan mengingat potensi yang dimiliki seperti minat untuk bekerja dan berusaha cukup besar maka dipandang perlu untuk melakukan edukasi pengelolaan BUMDes dan sumber daya desa sebagai pilar PPKM perdesaan pada masa pandemi.

Pada tahap awal, tim terlebih dahulu melakukan observasi dan wawancara dengan pemerintah desa setempat, pengelola BUMDes, beberapa elemen masyarakat. Hal ini dimaksudkan untuk mendapatkan informasi sekaligus memperoleh izin dalam melaksanakan program pengabdian. Setelah mendapatkan persetujuan dan respon positif dari semua pihak, tim pelaksana melanjutkan koordinasi pelaksanaan program. Baik dari persiapan administrasi, kesiapan waktu peserta dan kesediaan narasumber. Hal ini didiskusikan bersama pihak mitra (pemerintah desa dan pengelola BUMDes). Metode yang digunakan yaitu edukasi dalam bentuk pelatihan dan pendampingan pengelolaan BUMDes, peran dan partisipasi masyarakat dalam menggunakan unit usaha yang dijalankan BUMDes. Selanjutnya, menggunakan metode edukasi dan pendampingan dalam membangun jaringan kemitraan antar desa dalam 
pengelolaan BUMDes.

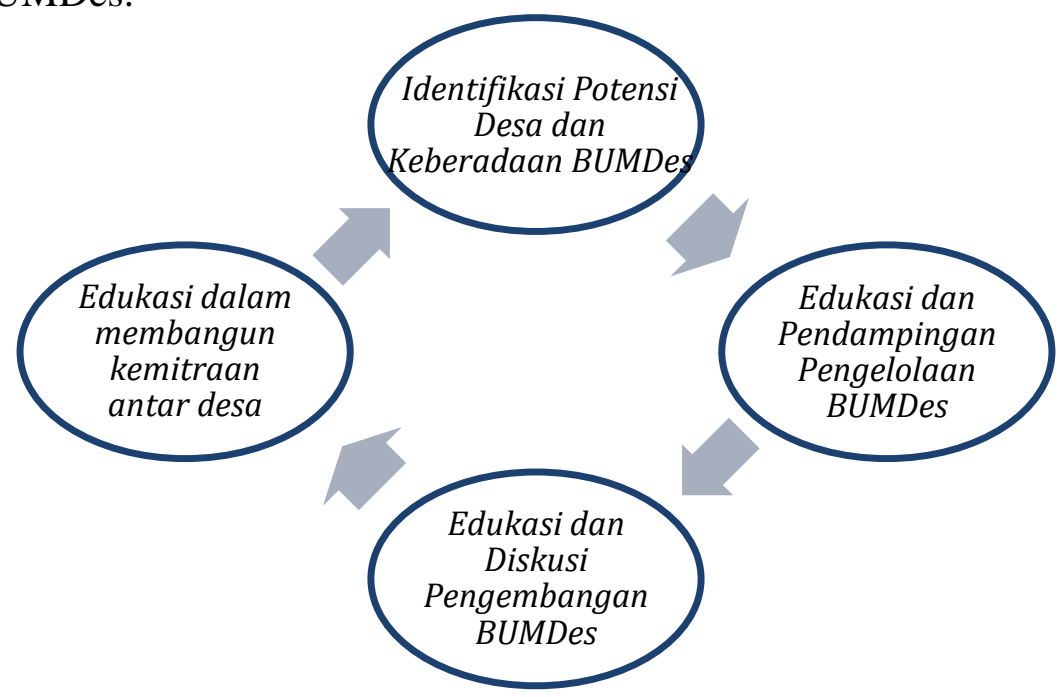

Gambar 1. Diagram Tahapan Program Pengabdian

\section{Hasil}

Program pengabdian ini dilaksanakan di Aula Kantor Desa Karyamukti pada tanggal 16 oktober 2021. Kegiatan ini dihadiri oleh Camat Mootilango, Narasumber dari akademisi, aparat desa, pengelola BUMDes, Badan Perwakilan Desa, Karang Taruna dan elemen masyarakat yang sempat hadir baik dari Desa Paris maupun Desa Karyamukti. Pada tahap awal, peserta mendapatakan arahan dari Camat Mootilango terkait kondisi dan keberadaan BUMDes di Kecamatan Mootilango. Elemen masyarakat diminta untuk lebih aktif dalam menjawab segala masalah yang dihadapi dalam pengelolaan BUMDes. Pemerintah desa diminta untuk mendata Pengelola BUMDes dari kedua desa yang tidak sempat menghadiri kegitan. Selanjutnya pemaparan materi dan diskusi dilanjutkan oleh narasumber dari kalangan akademisi yang juga tim pelaksana pengabdian. Materi pertama dari tim pelaksana yang disajikan oleh Boby Rantow Payu, S.Si., ME dengan judul materi "Bagaimana Peran Bumdes sebagai Motor Perekonomian Desa?". Materi kedua dari tim pelaksana yang disajikan oleh Abdulrahim Maruwae, S.E., M.Pd dengan judul materi "Edukasi Penyusunan Rencana Bisnis/Usaha BUMDes". Penyajian materi yang dilakukan dengan metode brainstorming, membuat diskusi menjadi menarik dan berkembang. Hal ini selanjutnya melahirkan rekomendasi penataan BUMDes, kesadaran peran untuk mengambil tanggung jawab dan semangat kerja sama untuk membangun BUMDes sebagai penggerak perekonomian desa.

\section{Diskusi}

Dari hasil diskusi diperoleh informasi bahwa BUMDes di Desa Paris bergerak dibidang jasa seperti peminjaman tenda dan kursi. Sebelumnya pernah merintis usaha minyak kelapa tetapi tidak berkembang. Komposisi pengelola/pengurus juga mengalami beberapa kali rotasi dan pergantian. Kondisi yang berbeda pada BUMDes di Desa Karyamukti yang bergerak dibidang usaha penjualan sarana produksi pertanian, obat dan bibit jagung. Komposisi pengelola/pengurus sejak pembentukan hingga saat ini tergolong berjalan dengan sangat baik. 
Jenis usaha yang dikembangkan oleh BUMDes di Desa Paris dan Desa Karyamukti sudah sesuai dengan contoh usaha yang dapat dikembangkan yang tertuang dalam Permendesa Nomor 4/2015 tentang Pendirian, Pengurusan dan Pengelolaan, dan Pembubaran Badan Usaha Milik Desa Pasal 19. Namun demikian belum sepenuhnya mencapai tujuan yang tercantum pada Permendesa Nomor 4 Tahun 2015 Pasal 3 yang menyatakan bahwa BUMDes dibentuk dengan berbagai ragam tujuan, yaitu: a) meningkatkan perekonomian desa; b) mengoptimalkan aset desa agar bemanfaat untuk kesejahteraan desa; c) meningkatkan usaha masyarakat dalam mengelola potensi ekonomi desa; d) mengembangkan rencana kerja sama usaha antar desa dan/atau dengan pihak ketiga; e) menciptakan peluang dan jaringan pasar yang mendukung kebutuhan layanan umum warga; f) membuka lapangan kerja; g) meningkatkan kesejahteraan masyarakat melalui perbaikan pelayanan umum, pertumbuhan dan pemerataan ekonomi desa; dan h) meningkatkan pendapatan masyarakat desa dan Pendapatan Asli Desa (PAD).

Memperhatikan kondisi di atas serta mencermati pandangan dan respon dari peserta kegiatan, maka seluruh elemen masyarakat harus memiliki kesamaan pandangan dalam pengelolaan. BUMDes punya peran penting dan strategis sebagai motor penggerak ekonomi desa. Untuk itu penguatan peran bumdes mutlak perlu selalu dilakukan. Dalam penguatan ekonomi desa, bumdes tidak hanya berorientasi profit namun juga harus berperan dalam memberdayakan masyarakat di desa. Untuk mencapai tujuan tersebut maka dalam memilih usaha yang akan dikembangkan, bumdes seharusnya memilih usaha-usaha yang sesuai dengan potensi desa dan tidak susah dijalankan oleh masyarakat.

Dalam pengelolaannya, seluruh elemen masyarakat baik pemerintah desa maupun masyarakat harus mengambil peran sebagai inisiator dalam keberhasilan dan keberlanjutan BUMDes. Dengan tetap memperhatikan beberapa indikator yang sangat menentukan perkembangan BUMDes (Buku 9 Modul BUMDes, Praktek Baik BUMDes di Kabupaten Bantul), seperti kepemimpinan, pemilihan potensi usaha, potensi kelayakan usaha, sumber daya manusia dan modal.

Kerja sama yang terjalin erat antara pemerintah desa, pengelola BUMDes, dengan seluruh elemen masyarakat menjadi poin utama dalam menjadikan BUMDes memiliki peran strategis di desa. Seperti pada kondisi pandemi saat ini, BUMDes dapat berperan sebagai pilar PPKM (Penggerak Perekonomian Kawasan Masyarakat) Perdesaan yang menopang kesejahteraan masyarakat dan kemandirian desa.

\section{Kesimpulan}

Program pemberdayaan masyarakat melalui edukasi pengelolaan BUMDes dan sumber daya desa yang dilaksanakan di Aula Kantor Desa Karyamukti pada tanggal 16 oktober 2021 bagi pengelola BUMDes, aparat desa, pengurus BPD, karang taruna dan elemen masyarakat baik dari Desa Paris maupun Desa Karyamukti berjalan dengan sukses dan memperoleh respon yang positif dari pemerintah Kecamatan Mootilango, aparat Desa Paris dan Desa Karyamukti, pengelola BUMDes dan elemen masyarakat lainnya.

Pengelola BUMdes dapat memilih usaha-usaha yang sesuai dengan potensi desa dan tidak susah dijalankan oleh masyarakat. Di samping itu, seluruh elemen masyarakat baik pemerintah desa maupun masyarakat harus mengambil peran sebagai inisiator dalam keberhasilan dan keberlanjutan BUMDes. Komitmen pengelolaan baik dari aspek kepemimpinan, pemilihan potensi usaha, potensi kelayakan usaha, sumber daya manusia dan modal menjadi mutlak untuk selalu dikembangkan. 


\section{Pengakuan/Acknowledgements}

Ucapan terima kasih disampaikan kepada:

1. Universitas Negeri Gorontalo atas dukungannya sehingga program pengabdian ini bisa terlaksana.

2. Pemerintah Kabupaten Gorontalo, Pemerintah Kecamatan Mootilango atas dukungannya sehingga program pengabdian ini bisa terlaksana.

3. Pihak Pemerintah Desa, Pengelola BUMDes, Pengurus BPD, elemen masyarakat Desa Paris dan Desa Karyamukti yang telah berkenan menjadi mitra dalam kegiatan ini dengan memfasilitasi ruang pengembangan BUMDes.

\section{Daftar Referensi}

Darwita, I.K., Redana, D.N. (2018). Peranan Badan Usaha Milik Desa (BUMDes) dalam Pemberdayaan Masyarakat dan Penanggulangan Pengangguran di Desa Tejakula Kecamatan Tejakula Kabupaten Buleleng, Jurnal Universitas Panji Sakti, Locus Majalah Ilmiah FISIP Vol. 9 (1) 51-60

Prasetyo, Ratna Azis. (2016). Peranan BUMDes dalam Pembangunan dan Pemberdayaan Masyarakat di Desa Pejambon Kecamatan Sumberrejo Kabupaten Bojonegoro, Jurnal Dialektika Vol. XI (1) 86-100

Modul KKN Tematik Desa Membangun, Badan Usaha Milik Desa (2019) Pusat Penelitian dan Pengembangan, Badan Penelitian dan Pengembangan, Kementerian Desa Pembangunan Daerah Tertinggal dan Transmigrasi

Peraturan Menteri Desa, PDT dan Transmigrasi No. 4 Tahun 2015 Tentang Pendirian, Pengurusan dan Pengelolaan, dan Pembubaran Badan Usaha Milik Desa

TNP2K (Tim Nasional Percepatan Penanggulangan Kemisikinan). (2020) Ringkasan Kebijakan Pendayagunaan Badan Usaha Milik Desa Dalam Pemulihan Ekonomi Pascawabah Covid-19 